The career aspirations and action behaviours of Australian adolescents in out-of-home care

Peter A Creed ${ }^{1}$, Clare Tilbury ${ }^{2}$, Nick Buys ${ }^{2}$, and Meegan Crawford ${ }^{2}$

${ }^{1}$ School of Applied Psychology, and Griffith Health Institute

${ }^{2}$ School of Human Services and Social Work, and Griffith Health Institute 


\title{
The career aspirations and action behaviours of Australian \\ adolescents in out-of-home-care
}

\begin{abstract}
We surveyed 202 adolescents who were in out-of-home care, and compared them with 202 adolescents not in care (matched for age, gender and school achievement) on career-related aspirations (occupational aspirations, educational aspirations, life barriers) and career action behaviours (career exploration, career planning). The outof-home care adolescents reported lower occupational aspirations, less career planning, more career barriers, lower educational aspirations for themselves, lower parental aspirations, and more school engagement. Further, career exploration was lower for out-of-home care children who had higher aspirations, lower self-efficacy, parents who communicated higher aspirations, and low aspiring friends. Results are discussed in the context of providing career development and supports for out-ofhome care adolescents so that their career aspirations and behaviours can mirror more normative levels.
\end{abstract}

Keywords: out-of-home care; career development; career aspirations; educational aspirations; career exploration; career planning 
Children in "out-of-home" care are those who have been placed under the legal custody or guardianship of the State for their care and protection (Australian Institute of Health and Welfare [AIHW], 2009). These children come from struggling families where parenting skills and resources are limited (Barber, Delfabbro, \& Cooper, 2000). They are no longer able to live with their family of origin, for example, because of child abuse or neglect, and come to the attention of State agencies via concerned community members, health and welfare professionals, teachers, and the police, some of whom are mandated to report such incidents. Typically, the children are placed with foster carers or extended family members, although in some cases they may be placed in residential care. This use of out-of-home care is considered a last option; thus, only children in serious need are placed in out-of-home care in this way (Bromfield \& Osborn, 2007).

The number of children in out-of-home care in Australia has grown dramatically over the past decade, more than doubling from 14,078 in 1997 to 31,166 in 2008. The rate of children in care also has grown, from 3.3 to 6.0 per 1,000 over the same time period. About half of these children are cared for in foster homes, $44 \%$ are in care with relatives or kin, and $4 \%$ are in residential situations (AIHW, 2008). Some other Western countries are seeing a decline in the number of children in out-of-home care. For example, in the US, while there was an increase in children in care during the 1990s (6.2 to per 1,000 in 1990 to 8.1 per 1,000 in 1999), this has declined to 5.7 per 1,000 in 2009 (Child Trends Data Bank, 2009). Similarly, in the UK, the number of children in out-of-home care in 2007 was a 2\% decrease from 2003 (Department for Children, Schools and Families, 2007). One of the main reasons for the increased numbers of children in care in Australia is that the length of time in care has increased (AIHW). 
Children in out-of-home care are clearly disadvantaged relative to their not in care peers. First, and by definition, they have a history of disadvantage and/or abuse prior to being placed in care (Fernandez, 1996). Second, they have to manage the losses and disruptions that go along with being placed in care (Cashmore, Paxman, \& Townsend, 2007), at the same time as coping with the effects of past neglect and/or abuse (O’Neill, 2004). Contact with siblings, friends and extended family are typically disrupted, and they may have to deal with a series of case workers and placement instability (Barber \& Delfabbro, 2003). On top of this, they may receive inadequate or inappropriate services from the agencies charged with helping them (Bromfield \& Osborn, 2007; Pinkerton \& Stein 1995).

The outcomes and life achievements for children in out-of-home care, once they leave care, are also poorer than children who were not in care (Farruggia, Greenberger, Chen, \& Heckhausen, 2006). When young people leave care they have higher rates of homelessness (Maunders, Liddell, Liddell, \& Green, 1999), offending (Courtney et al., 2005), substance abuse, relationship difficulties (Buehler, Orme, Post, \& Patterson, 2000), mental health problems (Cook-Fong, 2000), income support needs (Dworsky, 2005), and unemployment, under-employment and underachievement in the workforce (Blome, 1997; Cashmore \& Paxman, 1996; Stein, 1994). The long-term outcomes for out-of-home care Australian children has been summarised by Osborn and Bromfield (2007). These authors reported findings consistent with international results, and concluded that "young people leaving care are one of the most vulnerable and disadvantaged social groups” (p.2).

While some children in out-of-home care manage the transition from school to work satisfactorily, many are poorly prepared for independent living. Children in outof-home care in Australia receive legal protection and formal assistance from the 
State only until they are 18 years of age. This means that, at the age of 16,17 or 18 years, when their not in care peers are either leaving school and entering the labour market or enrolling in further education with the help of their parents, children in outof-home care may be managing these transitions on their own. Some will receive ongoing support from a foster carer, but many will not (Courtney \& Dworsky, 2006; Mendes \& Moslehuddin, 2004). Young people transitioning from out-of-home care experience high rates of mobility (e.g., they are much more likely to experience transitional housing than not in care peers), are more likely to terminate their education early (e.g., only $42 \%$ of care leavers, compared to $80 \%$ of those in the general population, complete Year 12), are more likely to become early parents (e.g., about one third of young women leaving care become pregnant or give birth before the age of 20 , compared with $2 \%$ in the general population), have higher rates of unemployment and income support, struggle financially, and do not have the financial (or social or emotional) support to fall back on that young people not in care do (Allen, 2003; Bromfield \& Osborn, 2007; Paxman, 2007).

Crucial also to a successful transition are those early decisions that determine the educational and occupational pathways that are to be followed. Most adolescents make these decisions with the support of parents and family, whereas young people in out-of-home care are deciding on their future while experiencing and managing uncertainty and instability (Bromfield \& Osborn, 2007). Many of these decisions are driven by the needs of the school system, which require students to make careerrelated choices, such as selecting school subjects or educational streams, at regular intervals during the high school years. This occurs whether students are developmentally ready for the decision or not, and these decisions often lock young people into a particular career or occupational pathway from which it is difficult to 
deviate (Creed, Prideaux, \& Patton, 2005). In Australia, for example, Year 10 students can choose school subjects that have a specific occupational focus (these can be offered in the high school or in a technical college separate from the high school). Choosing vocationally-orientated subjects can orientate students towards early work entry, rather than have them focus on university-level training, and, for some students, may mean that they do not complete pre-requisites for later university programs (Alloway, Dalley, Patterson, Walker, \& Lenoy, 2004).

Despite the large volume of research that has examined the experiences of young people in out-of-home care (e.g., Landsverk, Burns, Stambaugh, \& Rolls Reutz, 2009; Naccarato \& DeLorenzo, 2008), there has been virtually no research investigating their career development and decision-making. Further, most intervention programs established to assist labour market entry for this population have focused on former in care young people (Henig, 2009), and primarily deliver training on job-seeking and developing workplace skills (e.g., Sherman, 2004), although some programs also offer career guidance services (Allen, 2003).

The current study sought to contribute to the understanding of the experiences of this population by examining the career development of a group of out-of-home care adolescents. We utilised the social cognitive career theory (Lent, Brown, \& Hackett, 1996), which is based on Bandura's (1986) personal agency theory, as the basis for this investigation. Social cognitive career theory proposes that there are three key variables that underpin agency in the career development domain, and which act as mechanisms for driving career-related actions (such as career exploration and planning). These are self-efficacy ("people’s judgements of their capabilities to organise and execute courses of action”; Bandura, p. 391), outcome expectations (people's judgements of the likely consequence of attempting a task; i.e., the 
contingency relationship between effort and outcome) and career goals or aspirations (people's intention to engage in a certain activity or to effect a particular outcome; Bandura), all of which have been described as the "building blocks" of career development (Lent et al.).

Salient to the current study, social cognitive career theory also acknowledges that contextual influences play an important role in the development of occupational interests and career decision-making, and may directly influence the development of self-efficacy, expectations of the future, and career aspirations. Contextual influences include gender, ethnic background, socio-economic status, personal resources, perceived life barriers, and educational supports and encouragements. The theory especially highlights connections between educational supports and encouragements and career aspirations (Lent et al., 1996). The suggestion here is that encouragement for academic achievement and tangible supports lead to more and better educational opportunities, which, in turn, lead to interest in more prestigious occupations, and help shape final career selection. Considerable support exists in the literature for the main proposals of the social cognitive career theory, as well as for the role of contextual influences (Lent, 2005; Sheu, Lent, Brown, Miller, Hennessy, \& Duffy, 2010).

We were interested in career aspirations, career exploration and career planning as outcome variables for the study. Career aspirations, which are "an individual's expressed career-related goals or choices” (Rojewski, 2005, p. 132), represent career goals in social cognitive career theory. They are important as they are useful predictors of occupational choices, and are associated with future occupational achievement (Mau \& Bikos, 2000; Schoon \& Parsons, 2002). Career exploration and planning represent action behaviours: career planning refers to activities such as 
setting sub-goals, deciding on strategies, prioritising tasks and identifying timelines, whereas career exploration refers to the information gathering needed for planning, such as identifying one's interests and values, and finding out information about education, training courses and occupations (Zikic \& Klehe, 2006). Both activities are important as they are actions that are taken to achieve the aspirations or goals of the individual (Lent et al., 1996). We were interested also in contextual influences, as adolescents in out-of-home care are subject to extraordinary experiences not confronted by their not in care peers. These were operationalised as career barriers, which can be considered as events or conditions within the environment that make career progress difficult. Real and/or perceived barriers are important determinants in the career choice process (Lent, 2005). Consistent with social cognitive career theory, we also assessed career-related self-efficacy and outcome expectations.

A major weakness with many studies of children in out-of-home care is the failure to include a comparison group (Farruggia et al., 2006). Utilising a comparison group allows stronger statements to be made about similarities and differences between those in out-of-home care and those not in care. Without a comparison group, it is difficult to know whether identified difficulties and strengths are specific to the outof-home care group, or are typical of adolescents from similar socio-economic backgrounds, but not in care. We assessed similarities and differences between a group of out-of-home care adolescents and a matched sample of adolescents not in care, constructed by controlling for gender, age and educational achievement, all variables influential to career development (Patton \& Creed, 2001).

While the study was somewhat exploratory, as no previous study has examined the career development of young people in out-of-home care, we were guided by the general out-of-home care literature, and expected (a) that those in out-of-home care 
would have lower career aspirations than those not in care. Guided by social cognitive career theory, we expected (b) that, as a consequence of the lower aspirations, the in out-of-home care adolescents would engage in fewer career action behaviours (i.e., less career exploration and planning), and (c) report more career-related barriers than those not in care. We were also interested in the correlates of aspirations and career exploration and planning, and again, based on social cognitive career theory, expected (d), that career goals and action behaviours would be differentially associated with the social cognitive career theory antecedents and contextual influences for the two groups. Finally, (e), as career trajectories differ for boys and girls (Patton \& Creed, 2001), we examined the effect of gender on these relationships.

\section{Method}

\section{Participants}

We collected data on two samples of young people. The first was of young people who were in out-of-home care in the State of Queensland, Australia. At the time of the study, there were approximately 1850 children aged between 10 and 18 years in care in Queensland (AIHW, 2009). Our target sample was the 1267 children in out-ofhome care aged between 13 and 18 years. We distributed surveys to the children by post using addresses provided by the agency responsible for them. Two hundred and sixty-five children returned a survey. This reflected a response rate of approximately 21\%; however, given the residential instability for many children in out-of-home care, and the lag between a change in address and updating the agency's data base, the real response rate for the study was likely to be higher than this. We omitted 63 surveys from this study as the children had either left school and were in the labour market, were parenting, or had extensive missing data. The remaining 202 comprised 117 girls (58\%) and 85 boys, whose average age was 15.2 years $(S D=1.3$ years; Range $=12.9$ 
to 18.2 years). All but nine children said they were born in Australia or New Zealand, with 161 (80\%) being Caucasian, 32 (16\%) indicating an Indigenous Australian heritage, and seven (4\%) being of Maori/Pacific Islander, Asian or African background (two children did not answer this question).

We also surveyed 378 children from three schools (two urban and one rural), who were not in the care of the State. These children completed the same survey as the out-of-home care group and were used to form a matched cohort comparison group, which allowed for stronger statements to be made about the out-of-home care group (van de Vijver \& Leung, 1997). The procedure for constructing the comparison group was to take an individual child from the out-of-home care group and match that child with one who was not in care, using the characteristics of gender, age and selfreported school achievement (“Overall, what school grades do you typically get?”; response range from 1 = pretty low - bottom $10 \%$, to $5=$ pretty high - top $10 \%$ ). This procedure resulted in 202 not in care children being included in the study. This group comprised the same number of girls $(117 ; 58 \%)$ and boys (85) as in the out-of-home care group. Their average age was 15.3 years $(S D=1.3$ years; Range $=12.9$ to 18.3 years), and all but 13 reported being born in Australia or New Zealand, with 171 (85\%) being Caucasian, 11 (5\%) indicating an Indigenous Australian heritage, 11 (5\%) being of Maori/Pacific Islander background, and eight (5\%) with an Asian or African background. As a group, the not in care children did not differ statistically from the out-of-home care children on gender composition, age, or school achievement.

While we matched the two groups on these three variables, the children in out-ofhome care were still likely to differ from the not in care children on a range of sociodemographic variables, such as the age and socio-economic level of their adult carers 
(Barber \& Delfabbro, 2003). It was also possible that some of the children not in outof-home care were subject to neglect and/or abuse. We had no way of determining whether this was the case or not, although we doubt there were many children experiencing neglect to the same level as the children in out-of-home care, as these children should have been identified by community agencies. Still, confounds remained that might influence outcomes of any comparison between the two groups. With this in mind, the comparisons can be considered to be between one group of children currently in out-of-home care and with a confirmed history of neglect and/or abuse, and a comparison group, which contained children not in care.

\section{Materials}

We assessed (a) career-related aspirations, career action behaviours (planning and exploration), self-efficacy, outcome expectations and barriers; and (b) educationrelated aspirations of self, parents and friends, school stability, and school engagement. Unless otherwise indicated, students responded using a 5-point Likertlike scale, with endpoints of strongly disagree (1) and strongly agree (5). Unless otherwise indicated, higher scores represented higher levels of a construct.

Career aspirations. We used four items from the Aspiring to Leadership and Promotions subscale of the Career Aspirations Scale (O’Brien, 1996), which tapped aspirations to being promoted and becoming a leader in your chosen occupation. We selected four items based on factor analyses reported by Gray and O’Brien (2007). A sample item was, "When I am established in my working life, I would like to manage other workers”. A factor analysis identified a single factor, which accounted for $62 \%$ of the variance, and contained factor loadings that ranged from .59 to .79 ; alpha $=.80$.

Occupational aspirations (type and complexity). We used a single open-ended question, devised by Looft (1971) and used widely in the literature (e.g., Watson, 
Quatman, \& Edler, 2002), which asked: “If you were completely free to choose any job you like, what job would you MOST LIKE to have?”. We then (a) classified written responses according to type using Holland's (1997) RIASEC coding system, and (b) rated the job aspired to on the level of job complexity using the Dictionary of Holland Occupational Codes (Gottfredson \& Holland, 1996). The RIASEC coding system allows occupations to be grouped into job families (e.g., "S" or "Social" occupations attract/require people with an interest in helping or teaching others, and include jobs such as nurse, teacher's aide and dental hygienist; "I” or "Investigative" occupations suit people who enjoy analysing, solving problems and doing research). The job complexity rating provides an estimate of the skills and training required to meet the mental demands of the job (e.g., medical practitioner is rated as high complexity, whereas farmer is rated as low). The range of scores for job complexity was 43 to 77 for both groups, with higher scores indicating more complex occupations. Complexity ratings of 65 or higher reflect occupations that require tertiary level education and substantial on-the-job experience, whereas ratings of 40 and below reflect occupations that require little formal training.

Career action behaviours of exploration and planning. We used two subscales of the short form of the Career Development Inventory (Creed \& Patton, 2004; Lokan, 1984), which was devised for use with students in Grades 8 to 12. Exploring potential career options and planning for the future reflect actions one might take to make progress towards life and career goals. The Career Exploration subscale (8 items) measures the range and usefulness of career exploration undertaken (e.g., "Would you ask any of these people for information or help to make plans for work or further education...?”, with options such as "teachers and guidance officers"), while the Career Planning subscale (10 items) measures the type and degree of career planning 
undertaken (e.g., "How much have you thought and planned about choosing a career in general?”, with endpoints of Not much at all and A great deal). Internal reliability coefficients for the two subscales have been reported as .73 (Exploration) and .87 (Planning), and validity has been demonstrated using factor analysis, testing associations with other variables, and by testing age and gender differences (Creed \& Patton). Alphas for the two scales were .73 (Exploration) and .87 (Planning).

Career decision self-efficacy. We used nine items based on a scale devised by Fouad, Smith, and Enochs (1997) to measure how confident the students were in carrying out the tasks related to choosing a career. A sample item was, "How confident are you that you could decide what job would be best for you?”. A factor analysis indicated one factor accounting for $55 \%$ of the variance, with factor loadings ranging from .45 to $.82 ;$ alpha $=.89$.

Career outcome expectations. As we considered the few existing outcome expectations scales did not adequately assess career contingency relationships, we constructed nine questions based on the Career Decision Making Outcome Expectancy Scale, devised by Fouad et al. (1997). A sample item was, “The time I spend deciding upon the right job will be worth it”. A factor analysis indicated one factor accounting for $60 \%$ of the variance. Factor loadings ranged from .73 to .83; alpha $=.91$.

Career barriers. We assessed these using a modified Perceived Barriers Scale (Howell, Frese, \& Sollie, 1977), which asked students to indicate, "How much will these keep you from getting the job you want?”, for 10 possible career barriers. A factor analysis identified two factors, which we labeled Perceived External Barriers (6-items: e.g., “shortage of 'good' jobs”, “lack of information about job opportunities”), and Perceived Person Barriers (4-items: e.g., “your family 
background”, “your cultural background”). Factor loadings ranged from .43 to .71 (external) and .75 to .85 (person). The scales were correlated at .48 ; alphas $=.80$ (external) and .89 (person).

Educational aspirations. We were interested in assessing educational aspirations, as these are related to career aspirations (Rojewski, 2005), and interested in the influences of others, namely parents and peers, on career aspirations, as these have been shown to be associated with both career and educational aspirations (Buchmann \& Dalton, 2002). We created three single items to assess self ("What is the highest level of education you expect to complete?”; with seven options ranging from Year 10 to University), parental ("What is the highest level of education your parents would like you to complete?”; with seven options ranging from Year 10 to University) and peer educational aspirations ("How many of your school friends intend to complete year 12?”; four options ranging from Not many to All).

School stability. We asked students, "How many times have you moved school since starting in Year 8?”, and used a 3-point response format that ranged from Hardly at all (0-1times) to Many times (more than 5 times).

School engagement. We used a 10-item scale devised by the National Center for School Engagement (Finlay, 2006). A sample item was, "I enjoy the work I do in class”. A factor analysis identified a single factor, which accounted for $63 \%$ of the variance, and contained factor loadings that ranged from .65 to .83; alpha $=.93$.

\section{Procedure}

The study was cross-sectional, survey based, and conducted under the auspices of the authors' university ethics committee. The data form part of a larger mixedmethods study, in which we obtained information from young people in out-of-home care, caseworkers, foster carers and school personnel. The surveys were posted to the 
out-of-home care students, and distributed by the schools to the not in care students. Students' names were placed in a draw to win prizes as an encouragement to participate in the study.

\section{Results}

Differences between Out-of-home Care and Not In Care Groups

We conducted one MANOVA (with the career variables as dependent measures, and group [in out-of-home care vs. not in care] and gender as fixed factors), to test for differences between the two groups on the career variables and to test if differences were moderated by gender. There was a significant multivariate main effect for group, $F(7,394)=4.12, p<.001$, but no gender, $(p=.46)$, or gender $\mathrm{x}$ group effect, $(p=$ .77). Using a correction for multiple groups of $p<.007$, the out-of-home care group reported less career planning, $F(1,400)=8.51, p=.004$, than the not in care group. One other variable approached significance: the out-of-home care group reported higher levels of person barriers $(p=.03$ ). We conducted a second MANOVA (with the education variables as dependent measures, and group and gender as fixed factors), to test for differences between the two groups on the education variables. There was a significant multivariate main effect for group, $F(5,396)=12.07, p<$ .001 , and gender, $F(5,396)=2.67, p=.02$, but no significant gender $\mathrm{x}$ group interaction effect, $(p=.34)$. The out-of-home care group had lower educational aspirations for themselves, $F(1,400)=31.96, p<.001$, perceived their parents to have lower levels of educational aspirations for them, $F(1,400)=18.58, p<.001$, and experienced more school instability, $F(1,400)=24.71, p<.001$. One other variable approached significance (corrected level: $p<.01$ ); the out-of-home care group reported more school engagement, $(p=.04)$. 
As the sample size was slightly smaller for RIASEC occupational types and RIASEC job complexity scores $(N=187$, instead of 202 for the out-of-home care group; 15 students did not indicate their most desired job, or indicated jobs that could not be coded), we conducted separate ANOVA and chi-square analyses to test for differences on these two variables. The out-of-home care group aspired to lower complexity occupations than the not in care group, $F(1,385)=12.04, p=.001$. There was no effect for gender, $(p=.79)$, and no gender $\mathrm{x}$ complexity interaction effect, $(p=$ .49). See Table 1 for summary data. The out-of-home care group was also more likely to aspire to social type occupations, and less likely to aspire to investigative and artistic occupations, $\chi^{2}(6)=28.29, p<.001$.

\section{Insert Table 1 about here}

Correlates of Career Aspirations, Job Complexity and the Career Action Behaviours of Planning and Exploration

Using the full sample, we conducted four separate hierarchical multiple regression analyses to test if the correlates of career aspirations, job complexity, career planning and career exploration were different for the out-of-home and not in care groups. In these analyses, we included, in turn, career aspirations, job complexity, career planning and career exploration as the outcome variables. We included demographic variables at Step 1 if they were bivariately correlated with the outcome variable. We included all career and educational variables and a group variable $(1=$ in out-of-home care; $0=$ not in care) at Step 2. Then, to test if the relationship between the predictor variables and outcome variables was moderated by group membership, we included a series of interaction terms (e.g., career outcome expectations x group) at Step 3. The interaction terms were created by finding the product of the predictor and group 
variable (Aiken \& West, 1991). See Table 2 for bivariate correlations and Table 3 for summary data for the regression analyses.

\section{Insert Table 2 and Table 3 about here}

In these hierarchical multiple regression analyses, we found significant, additional variance explained when the interaction terms were included at Step 3 for the outcome variable of career exploration, but not for career aspirations, job complexity or career planning. There were significant, individual interaction terms identified for career aspirations (career planning x group), job complexity (school stability x group) and career planning (career aspirations $\mathrm{x}$ group), but these were not interpreted as the interaction terms as a group did not add to the model (Aiken \& West, 1991).

Four interaction terms were significant at Step 3 for career exploration (career aspirations x group, career decision self-efficacy x group, educational aspirations of parents $\mathrm{x}$ group, educational aspirations of friends $\mathrm{x}$ group). We explored these interactions using the computation tool provided by Preacher, Curran, and Bauer (2006), which generated simple regression equations that facilitated interpretation. See Figure 1. For career aspirations x group, as the students' aspirations increased, so too did the career exploration of both groups, although career exploration increased at a faster rate for the not in care group, suggesting that aspirations play a more positive role in exploration for the not in care group. For career decision self-efficacy x group, as self-efficacy increased, so too did the career exploration of both groups, but it increased at a faster rate for the out-of-home care group, suggesting that efficacy plays a more positive role in career exploration for the out-of-home care group. For educational aspirations of parents $\mathrm{x}$ group, as parental aspirations increased, the career exploration of both groups increased, but career exploration by the out-of-home care group increased at a lower rate than that for the not in care group; that is, parents' 
aspirations in the out-of-home group played less of a role in career exploration than parents' aspirations in the not in care group. For educational aspirations of friends $\mathrm{x}$ group, as friends' aspirations increased, so too did the career exploration of both groups, although the career exploration of the out-of-home care group increased at a higher rate than for the not in care group, suggesting that friends' aspirations were more important in the out-of-home care group.

\section{Discussion}

There were a number of strengths to this study. First, we tested for a comprehensive range of career development variables in a sample of adolescents in out-of-home care, which has not been undertaken previously. Second, we compared the out-of-home care group to a sample of not in care adolescents, matched for age, gender and self-reported school achievement, which is unusual because of the difficulty of obtaining a meaningful comparison group, but recommended methodology when examining out-of-home care experiences (Farrugia et al., 2006). Third, the study was informed by the widely utilized social cognitive career theory (Lent et al., 1996), which includes an assessment of contextual influences on career development.

We predicted that adolescents in out-of-home care would exhibit significant differences from adolescents not in care on wide range of career development variables. Our results suggested that the two groups did not differ on many of the variables of interest, although we did identify differences in some important areas. We found support for our expectations that there would be differences between those in out-of-home care and those not in care on career aspirations. While there were no differences between the two groups when asked about their career aspirations in relation to becoming a leader (based on the Aspiring to Leadership and Promotions 
scale; O’Brien, 1996), the out-of-home care group, when asked to indicate the job they would most like to have, were more likely to aspire to less complex occupations (i.e., occupations that required fewer skills and less training). Additional to this, the out-of-home care group was more likely to aspire to social type occupations and less likely to aspire to investigative and artistic occupations.

It is encouraging that both groups aspired to doing well and advancing within their careers. However, choosing less complex jobs reflects aspiring to occupations that are less prestigious, pay less, involve simpler tasks, require less training, less ability, and which are ultimately less satisfying (Gottfredson, 1996). While career aspirations are strongly associated with future occupational achievements (Rojewski, 2005), they also reflect past life and employment experiences and societal expectations (Gottfredson \& Becker, 1981). Although this study cannot confirm that out-of-home care experiences "caused" these lowered aspirations, it is plausible to suggest that they are related to past social and psychological disadvantage. Indeed, Rojewski and Hill (1998) argued that lower aspirations reflect self and/or systemic limitations that lead young people to limit themselves when considering future life and career opportunities.

As aspirations are "somewhat" malleable (Rojewski), out-of-home care adolescents may benefit from interventions that explore aspirations and allow them the opportunity to set comparable life and occupational goals. Such interventions need to be offered early as previous research has consistently found that aspirations tend to become more stable after age 14-15 years (Furlong \& Biggart, 1999; Rojewski \& Yang, 1997). Simply focussing on the out-of-home care children and elevating their life aspirations is, of course, insufficient, and may engender disappointment and distress in children whose opportunities and resources do not match children not in 
care. State agencies need to play their part and ensure that children in their care are provided with real opportunities and supports to allow them to realise enhanced life and career goals. The literature on children in out-of-home care is replete with calls for State agencies to fully engage with and adequately support these children (e.g., see AIHW, 2008, 2009).

The out-of-home care group also was more likely to aspire to social type occupations, and less likely to aspire to investigative and artistic occupations. The preference for social occupations may reflect out-of-home care adolescents' disproportionate exposure to helping professionals, such as police, welfare workers, counsellors and case-workers, who would have worked with the children in the process of them being removed from their family of origin and placed in care. Munson and Strauss (1993) indicated that young people are more likely to engage in social modelling of occupations they come across in their immediate environment. If this is the case, these young people could benefit from exploring a more diverse range of occupations. Investigative occupations, by-and-large, are also more prestigious and require more training (Holland, Fritzsche, \& Powell, 1997).

The out-of-home care group's relative disinclination to investigative occupations is likely to parallel their preference for less complex and challenging occupations reflected in their scores on the job complexity variable. Artistic occupations are associated with temperaments that prefer ambiguity, unsystematised activities and risk-taking, which may be inconsistent with in care experiences, which have been shown to foster the need for stability and order in children (Osborn \& Delfabbro, 2006). Whether these aspiration differences reflect a disproportionate exposure to a narrow range of occupations or reflect in care experiences, they need to be addressed 
so that out-of-home care adolescents do not focus on a restricted range of occupations that might limit their life achievements and satisfaction.

There were no significant differences between the two groups on career exploration, although the mean differences on this measure were in the expected direction, but the out-of-home care group reported less career planning. Career exploration and career planning can be characterised as actions or behaviours that are set in train to meet set career goals (Lent et al., 1996). Less planning implies that the out-of-home care group was giving less time and thought to their occupational future, including less time and thought to choosing educational pathways, and not having "clear plans" about how and when they might enter the labour market. Young people in out-of-home care may not plan because they may think they have little control over, or input into, decisions about their life, since important decisions, such as where they live, what school they attend and who they can have contact with, are frequently decided by others, such as caseworkers and foster parents, whose primary aim is the child's current safety, rather than their future occupational well-being. One of the most consistent findings in relation to children in out-of-home care is that they are educationally disadvantaged (CREATE Foundation, 2006; Pecora et al., 2006). The current findings add to this knowledge by suggesting that young people in out-ofhome care are not only not engaged with their education, but they also are not engaged with thinking about and planning for their future lives and careers, both of which are linked to educational engagement and attainment.

There was also a trend for the out-of-home care group to report higher perceptions of "person" barriers to their careers. These represent barriers related to their family background and where they lived, and plausibly reflect that the out-of-home care 
group is alert to their situation and construe it as a potential barrier to later occupational achievement.

Finally, the young people in out-of-home care were lower on almost all of the variables in the educational cluster: they had lower educational aspirations for themselves, believed their parents had lower educational aspirations for them, and reported less school stability. These results are consistent with previous research, which has shown that children in out-of-home care experience more disruptions to their schooling (resulting from placement changes, but also from school suspensions and expulsions) and finish school earlier (CREATE Foundation, 2006). School achievement and completion are crucial factors in determining life outcomes as adults (Parliamentary Committee on Children and Young People, 2002). The present study provides additional insight into these processes by demonstrating that educational aspirations for out-of-home care children as a group are not normative. There was a trend for the out-of-home care students to report higher school engagement, but given their lower educational aspirations, it would be useful to know if this result reflected an attachment to the social supports offered within the school or reflected an engagement with the educational process. As educational and occupational aspirations and achievements are intertwined (Rumberger, 1995), improved outcomes for out-ofhome care leavers need to involve raising levels of career awareness as well as fostering better educational outcomes. As the children's perceptions of parent expectations were low, it is important that significant adults in the child's life such as foster carers, caseworkers and school personnel play a role in raising expectations for this group.

When we tested for the correlates of career aspirations (leadership aspirations, job complexity) and career action behaviours (exploration, planning), we found no group 
effects for either career aspiration variable or for career planning. However, there were significant interaction effects for career exploration. As perceptions of parental aspirations and self aspirations increased, these were associated with disproportionately higher rates of career exploration for the not in care group, compared to the out-of-home care group. Conversely, as friends' aspirations increased, the career exploration of the out-of-home care group increased disproportionately moreso than the not in care group. Together, these results suggest a less positive role in career exploration for parent and self aspirations, and more of a role for friends’ aspirations in the out-of-home care group.

These results may reflect further disadvantage for the out-of-home care students who were less influenced by their own and perceptions of their parents' aspirations, and more influenced by the aspirations of friends. Career exploration involves seeking and integrating information about the self and the world of work, and includes engaging in future oriented speculation and reflecting on past activities (Zikic \& Klehe, 2006). Well-informed sources who can provide information and role models are likely to benefit most young people, and our results suggest that there could be particular benefits for improving this in young people in out-of-home care. Parents, and to a lesser extent, friends, are considered important influences on the educational and career development of young people in general (Otto, 2000; Whiston \& Keller, 2004). Where it is possible and safe to do, it is desirable, for many reasons associated with the child's development, that children in out-of-home care maintain contact with their parents, and this is wanted by out-of-home care children themselves (Scott, O’Neill, \& Minge, 2005). Our results, that parental influences may be less salient, and friends' influences may be more salient to career exploration may be because children in out-of-home care have reduced contact with parents and rely more on peers. We 
also found a significant effect for the career decision self-efficacy x group interaction. As self-efficacy increased, the out-of-home care group engaged in disproportionately more career exploration than the not in care group, indicating that the out-of-home care group responded more positively as they become more confident, suggesting a role here for developing career self-efficacy in out-of-home care children.

Several limitations need to be noted when considering the outcomes of the study. Although we obtained a large sample of adolescents in out-of-home care, it was a small proportion of the total children in out-of-home care in this age group, and not representative. It was likely to have contained a disproportionately greater proportion of out-of-home care children in stable situations, and children without reading difficulties, because of the survey-based design. Thus, it is possible that our sample contained fewer of the more disadvantaged children in out-of-home care than is representative of the population. We were able to match the adolescents in out-ofhome care with adolescents not in the care of the State based on gender, age and school achievements, but it should be acknowledged that, despite this, the two groups would still have differed based on other socio-demographic background variables. The study relied on self-reports, and would have benefitted by being augmented by reports from a second source, for example, carers or case workers. We also used several single item measures. Our aim here was to keep the survey as short as possible for this group, but it should be acknowledged that multi-item measures are more desirable. Finally, we used cross-sectional methodology, meaning that the associations found cannot be considered causal. Despite these limitations, the study identified many important differences between the adolescents in out-of-home care and their matched not in care counterparts and provided useful insights into how 
agencies who work with young people in out-of-home care youth might progress their policies and interventions related to the career development of this population.

\section{Acknowledgements}

The authors wish to acknowledge the assistance of the Australian Research Council and the Queensland Department of Communities (Child Safety Services) and the Queensland Department of Education and Training with this research.

\section{References}

Aiken, L., \& West, S. (1991). Multiple regression: Testing and interpreting interactions. Newbury Park, CA: Sage.

Allen, M. (2003). Into the mainstream: Care leavers entering work, education and training. York, UK: Joseph Rowntree Foundation.

Alloway, N., Dalley, L., Patterson, A., Walker, K., \& Lenoy, M. (2004). School students making education and career decisions: Aspirations, attitudes and influences. Canberra, ACT: Australian Government, Department of Education, Science and Training.

Australian Institute of Health and Welfare. (2008). Child protection Australia 20062007. Child Welfare Series No. 43. Canberra, ACT: Author.

Australian Institute of Health and Welfare. (2009). Child protection Australia 200708. Child Welfare Series No. 45. Canberra, ACT: Author.

Bandura, A. (1986). Social foundations of thought and action: A social cognitive theory. Englewood Cliffs, NJ: Prentice-Hall. 
Barber, J. G., \& Delfabbro, P. H. (2003). Placement stability and the psychosocial well-being of children in foster care. Research on Social Work Practice, 13, 415431.

Barber, J. G., Delfabbro, P. H., \& Cooper, L. (2000). Aboriginal and non-Aboriginal children in out-of-home care. Children Australia, 25, 5-10.

Blome, W. W. (1997). What happens to foster kids: Educational experiences of a random sample of foster care youth and a matched group of non-foster care youth. Child and Adolescent Social Work Journal, 14, 41-53.

Bromfield, L., \& Osborn, A. (2007). Getting the big picture: A synopsis and critique of Australian out-of-home care research. Melbourne: National Child Protection Clearinghouse, Australian Institute of Family Studies.

Buchmann, C., \& Dalton, B. (2002). Interpersonal influences and educational aspirations in 12 countries: The importance of institutional context. Sociology of Education, 75, 99-123.

Buehler, C., Orme, J. G., Post, J., \& Patterson, D. A. (2000). The long-term correlates of family foster care. Child and Youth Services Review, 22, 595-625.

Cashmore, J. A., \& Paxman, M. (1996). Wards leaving care: A longitudinal study. Sydney: Department of Community Services.

Cashmore, J., Paxman, M., \& Townsend, M. (2007). The educational outcomes of young people 4-5 years after leaving care: An Australian perspective. Adoption and Fostering, 31, 50-60.

Child Trends Data Bank (2009). Foster care. Retrieved from http://www.childtrendsdatabank.org/?q=node/199

Cook-Fong, S. K. (2000). The adult well-being of individuals reared in family foster care placement. Child Youth Care Forum, 29, 7-25. 
Courtney, M. E., \& Dworsky, A. (2006). Findings from the Milwaukee TANF applicant study. Chicago, IL: University of Chicago, Chapin Hall Center for Children.

Courtney, M. E., Dworsky, A., Terao, S., Bost, N., Ruth, G., Keller, T., \& Havlicek, J. (2005). Midwest evaluation of the adult functioning of former foster youth. Chicago, IL: University of Chicago, Chapin Hall Center for Children.

CREATE Foundation. (2006). Report card on education 2006. Sydney, NSW: CREATE Foundation.

Creed, P. A., \& Patton, W. (2004). The development and validation of a short form of the Career Development Inventory - Australia. Australian Journal of Guidance and Counselling, 14, 125-138.

Creed, P. A., Prideaux, L., \& Patton, W. (2005). Antecedents and consequences of career decisional states in adolescence. Journal of Vocational Behavior, 67, 397412.

Department for Children, Schools and Families (2007). Children looked after in England (including adoption and care leavers) year ending 31 March 2007. Retrieved from http://www.dcsf.gov.uk/rsgateway/DB/SFR/

Dworsky, A. (2005). The economic self-sufficiency of Wisconsin's former foster youth. Children and Youth Services Review, 27, 1085-1118.

Farruggia, S. P., Greenberger, E., Chen, C., \& Heckhausen, J. (2006). Perceived social environment and adolescents' well-being and adjustment: Comparing a foster care sample with a matched sample. Journal of Youth and Adolescence, 35, 349-358.

Fernandez, E. (996). Significant harm: Unravelling child protection decisions and substitute care careers of children. Aldershot, UK: Ashgate. 
Finlay, K., \& National Center for School Engagement. (2006). Quantifying school engagement: Research report. Retrieved from http://www.schoolengagement.org/TruancypreventionRegistry/Admin/Resources/ Resources/111.pdf.

Fouad, N. A., Smith, P. L., \& Enochs, L. G. (1997). Reliability and validity evidence for the middle school self-efficacy scale. Measurement and Evaluation in Counseling and Development, 30, 17-31.

Furlong, A., \& Biggart, A. (1999). Framing 'choices': A longitudinal study of occupational aspirations among 13 to 16 year olds. Journal of Education and Work, 12, 21-35.

Gottfredson, G. D. (1996). Prestige in vocational interests. Journal of Vocational Behavior, 48, 68-72.

Gottfredson, G. D., \& Holland, J. L. (1996). Dictionary of Holland occupational codes ( $3^{\text {rd }}$ ed.). Odessa, FL: Psychological Assessment Resources.

Gottfredson, L. S., \& Becker, H. J. (1981). A challenge to vocational psychology: How important are aspirations in determining male career development? Journal of Vocational Behavior, 18, 121-137.

Gray, M. P., \& O’Brien, K. M. (2007). Advancing the assessment of women's career choices: The Career Aspiration Scale. Journal of Career Assessment, 15, 317-337.

Henig, A. (2009). Employment aid for youth aging out of foster care: Extending one stop career centers to include a division for foster care youth. Family Court Review, 47, 570-585.

Holland, J. L. (1997). Making vocational choices: A theory of vocational personalities and work environments. Odessa, FL: Psychological Assessment Resources. 
Holland, J. L., Fritzsche, B. A., \& Powell, A. B. (1997). Self-Directed Search technical manual. Odessa, FL: Psychological Assessment Resources.

Howell, F. M., Frese, W., \& Sollie, C. R. (1977). Ginzberg's theory of occupational choice: A reanalysis of increasing realism. Journal of Vocational Behavior, 11, $332-346$.

Landsverk, J. A., Burns, B. J., Stambaugh, L. F., \& Rolls Reutz, J. A. (2009). Psychosocial interventions for children and adolescents in foster care: Review of research literature, Child Welfare, 88, 49-69.

Lent, R. W. (2005). A social cognitive view of career development and counselling. In S. D. Brown \& R. W. Lent, Career development and counselling: Putting theory and research to work (pp. 101-130). Hoboken, NJ: John Wiley \& Sons.

Lent, R. W., Brown, S. D., \& Hackett, G. (1996). Career development from a social cognitive perspective. In D. Brown \& L. Brooks (Eds.), Career choice and development (pp. 373-421). San Francisco, CA: Jossey-Bass Inc.

Lokan, J. (1984). Manual of the Career Development Inventory - Australian Edition. Melbourne, VIC: ACER.

Looft, W. R. (1971). Sex differences in the expression of vocational aspirations by elementary school children. Developmental Psychology, 5, 366-372.

Mau, W., \& Bikos, L. H. (2000). Educational and vocational aspirations of minority and female students: A longitudinal study. Journal of Counseling \& Development, 78, 186-194.

Maunders, D., Liddell, M., Liddell, M., \& Green, S. (1999). Young people leaving care and protection. Hobart, TAS: National Youth Affairs Research Scheme. 
Mendes, P., \& Moslehuddin, B. (2004). Graduating from the child welfare system: A comparison of the UK and Australian leaving care debate. International Journal of Social Welfare, 13, 332-339.

Munson, W. W., \& Strauss, C. F. (1993). Career salience of institutionalized adolescent offenders. The Career Development Quarterly, 41, 246-256.

Naccarato, T., \& DeLorenzo, E. (2008). Transitional youth services: Practice implications from a systematic review. Child and Adolescent Social Work Journal, 25, 287-308.

O'Brien, K. M. (1996). The influence of psychological separation and parental attachment on the career development of adolescent women. Journal of Vocational Behavior, 48, 257-274.

O'Neill, C. (2004). "I remember the first time I went into foster care - It's a long story...”: Children, permanent parents, and other supportive adults talk about the experience of moving from one family to another. Journal of Family Studies, 10, 205-219.

Osborn, A., \& Delfabbro, P. H. (2006). An analysis of the social background and placement history of children with multiple and complex needs in Australian outof-home care. Communities, Children and Families Australia, 1, 33-42.

Osborn, A., \& Bromfield, L. (2007). Research brief No. 7: Young people leaving care. Canberra, ACT: National Child Protection Clearing House: Australian Institute of Family Studies.

Otto, L. B. (2000). Youth perspectives on parental career influence. Journal of Career Development, 27, 111-118. 
Parliamentary Committee on Children and Young People (2002). Voices: The education experience of children and young people in out-of-home care. Sydney: Parliament House.

Patton, W., \& Creed, P. A. (2001). Developmental issues in career maturity and career decision status. The Career Development Quarterly, 49, 336-351.

Paxman, M. (2007). Young people leaving out-of-home care. Ashfield, NSW: Department of Community Services.

Pecora, P. J., Williams, J., Kessler, R. C., Hiripi, E., O'Brien, K., Emerson, J., Herrick, M. A., \& Torres, D. (2006). Assessing the educational achievements of adults who were formerly placed in family foster care. Child and Family Social Work, 11, 220-231.

Pinkerton, J., \& Stein, M. (1995). Responding to the needs of young people leaving state care: Law, practice and policy in England and Northern Ireland. Children and Youth Services Review, 17, 697-709.

Preacher, K. J., Curran, P. J., \& Bauer, D. J. (2006). Computational tools for probing interaction effects in multiple linear regression, multilevel modeling, and latent curve analysis. Journal of Educational and Behavioral Statistics, 31, 437-448. Retrieved from http://www.jstor.org/stable/4122453

Rojewski, J. W. (2005). Occupational aspirations: Constructs, meaning and application. In S. D. Brown \& R. W. Lent (Eds.), Career development and counselling: Putting theory and research to work (pp. 131-154). Hoboken, NJ: John Wiley \& Sons.

Rojewski, J. W., \& Hill, R. B. (1998). Influence of gender and academic risk behavior on career decision making and occupational choice in early adolescence. Journal of Education for Students Placed at Risk, 3, 265-287. 
Rojewski, J. W., \& Yang, B. (1997). Longitudinal analysis of select influences on adolescents’ occupational aspirations. Journal of Vocational Behavior, 51, 375410.

Rumberger, R. W. (1995). Dropping out of middle school: A multilevel analysis of students and schools. American Educational Research Journal, 32, 583-625.

Scott, D., O’Neill, C., \& Minge, A. (2005). Contact between children in out-of-home care and their birth families: Literature review. Sydney, AUS: NSW Department of Community Services.

Sherman, R. (2004). Serving youth aging out of foster care: The Finance project. Retrieved http://www.financeproject.org/Publications/servingyouthagingoutIN.pdf.

Schoon, I., \& Parsons, S. (2002). Teenage aspirations for future careers and occupational outcomes. Journal of Vocational Behavior, 60, 262-288.

Sheu, H-B, Lent, R. W., Brown, S. D., Miller, M. J., Hennessy, K. D., \& Duffy, R. D. (2010). Testing the choice model of social cognitive career theory across Holland themes: A meta-analytic path analysis. Journal of Vocational Behavior, 76, 252264.

Stein, M. (1994). Leaving care, education and career trajectories. Oxford Review of Education, 20, 349-360.

Van de Vijver, F. J. R., \& Leung, K. (1997). Methods and data analysis for crosscultural research. Newbury Park, CA: Sage.

Watson, C. M., Quatman, T., \& Edler, E. (2002). Career aspirations of adolescent girls: Effects of achievement level, grade, and single-sex school environment. Sex Roles: A Journal of Research 5, 323-345.

Whiston, S. C., \& Keller, B. K. (2004). The influences of family of origin on career development: A review and analysis. The Counseling Psychologist, 32, 493-568. 
Zikic, J., \& Klehe, U. (2006). Job loss as a blessing in disguise: The role of career exploration and career planning in predicting reemployment quality. Journal of Vocational Behavior, 69, 391-409. 
Table 1

Summary data for Analyses testing Differences between the Out-of-home Care $(N=$ 202) and Not In Care $(N=202)$ groups

\begin{tabular}{|c|c|c|c|c|}
\hline \multirow[b]{2}{*}{ Variables } & \multicolumn{2}{|c|}{ In Out-of-home Care } & \multicolumn{2}{|c|}{ Not In Care } \\
\hline & $M$ & $S D$ & $M$ & $S D$ \\
\hline \multicolumn{5}{|l|}{ Career variables } \\
\hline Career aspirations & 15.62 & 3.06 & 15.82 & 2.91 \\
\hline Job complexity $^{\text {a }}$ & 57.59 & 8.13 & 60.71 & $8.21 * * *$ \\
\hline Career exploration & 25.88 & 6.51 & 26.36 & 7.12 \\
\hline Career planning & 33.31 & 8.18 & 35.50 & $7.95 * *$ \\
\hline Career self-efficacy & 34.58 & 7.69 & 34.00 & 6.72 \\
\hline Career outcome expectations & 37.69 & 5.88 & 37.62 & 5.64 \\
\hline Perceived external barriers & 14.47 & 5.70 & 14.52 & 5.72 \\
\hline Perceived person barriers & 6.69 & 4.16 & 5.84 & $3.14^{*}$ \\
\hline \multicolumn{5}{|l|}{ Educational variables } \\
\hline Educational aspirations (Self) & 5.20 & 1.90 & 6.08 & $1.17 * * *$ \\
\hline Educational aspirations (Parents) & 5.37 & 1.65 & 6.01 & $1.66^{* * *}$ \\
\hline Educational aspirations (Friends) & 2.74 & .86 & 2.88 & .80 \\
\hline School stability & 1.34 & .60 & 1.09 & $.33 * * *$ \\
\hline School engagement & 37.59 & 8.77 & 35.78 & $8.21 *$ \\
\hline
\end{tabular}


Table 2

Bivariate Correlations Amongst all Variables $(N=404)$

\begin{tabular}{|c|c|c|c|c|c|c|c|c|c|c|c|c|c|c|c|c|c|c|}
\hline Variables & 1 & 2 & 3 & 4 & 5 & 6 & 7 & 8 & 9 & 10 & 11 & 12 & 13 & 14 & 15 & 16 & 17 & 18 \\
\hline 1. Career aspirations & - & .10 & $.44 * * *$ & $.52 * * *$ & $.52 * * *$ & $.56 * * *$ & .05 & -.02 & $.20 * * *$ & $.19 * * *$ & $.13^{* *}$ & .02 & $.17^{* *}$ & .05 & .04 & $.21 * * *$ & -.01 & -.03 \\
\hline 2. Job complexity ${ }^{\mathrm{a}}$ & & - & $.11^{*}$ & $.15^{* *}$ & $.11^{*}$ & .09 & -.07 & -.07 & $.39 * * *$ & $.36 * * *$ & $.15^{* *}$ & -.09 & $.12 *$ & -.00 & -.01 & $.29 * * *$ & .05 & $-.18^{* * *}$ \\
\hline 3. Career exploration & & & - & $.55^{* * *}$ & $.45^{* * *}$ & $.48 * * *$ & .06 & .06 & $.19 * * *$ & $.15^{* *}$ & $.16^{* *}$ & .04 & $.27 * * *$ & $.17 * *$ & -.06 & $.17 * *$ & -.06 & -.04 \\
\hline 4. Career planning & & & & - & $.66^{* * *}$ & $.63^{* * *}$ & .01 & .00 & $.27 * * *$ & $.23 * * *$ & $.20 * * *$ & -.04 & $.32 * * *$ & .08 & -.01 & $.34 * * *$ & .04 & $-.13 * *$ \\
\hline 5. Career self-efficacy & & & & & - & $.69 * * *$ & -.05 & -.07 & $.20 * * *$ & $.19 * * *$ & $.13^{* *}$ & .04 & $.31 * * *$ & .08 & .00 & $.32 * * *$ & .03 & .04 \\
\hline 6. Career outcome expectations & & & & & & - & -.03 & -.04 & $.20 * * *$ & $.21 * * *$ & $.16^{* *}$ & -.02 & $.41^{* * *}$ & -.04 & -.05 & $.34 * * *$ & -.02 & .01 \\
\hline 7. Perceived external barriers & & & & & & & & $.46^{* * *}$ & -.08 & -.04 & -.04 & $.14^{* *}$ & -.03 & -.01 & -.03 & -.05 & -.09 & -.01 \\
\hline 8. Perceived person barriers & & & & & & & & - & $-.15^{* *}$ & -.10 & -.03 & $.17^{* *}$ & -.01 & .02 & .00 & -.08 & $-.11^{*}$ & $.12 *$ \\
\hline 9. Educational aspirations (Self) & & & & & & & & & - & $.54^{* * *}$ & $.29 * * *$ & $-.27 * * *$ & $.10^{*}$ & .02 & $-.13^{* *}$ & $.30 * * *$ & .04 & $-.27 * * *$ \\
\hline 10. Educational aspirations (Parents) & & & & & & & & & & - & $.28 * * *$ & $-.12 *$ & $.11 *$ & .09 & -.01 & $.25^{* * *}$ & .07 & $-.22 * * *$ \\
\hline 11. Educational aspirations (Friends) & & & & & & & & & & & - & $-.16^{* *}$ & $.27^{* * *}$ & .10 & -.08 & $.23 * * *$ & .05 & -.08 \\
\hline 12. School stability & & & & & & & & & & & & - & -.07 & $.22 * * *$ & -.04 & .01 & -.05 & $.25^{* * *}$ \\
\hline 13. School engagement & & & & & & & & & & & & & - & -.08 & .00 & $.25^{* * *}$ & -.05 & $.11^{*}$ \\
\hline 14. Age & & & & & & & & & & & & & & - & -.09 & .04 & .03 & -.01 \\
\hline 15. Gender ${ }^{b}$ & & & & & & & & & & & & & & & - & -.06 & $.11^{*}$ & .00 \\
\hline 16. School & & & & & & & & & & & & & & & & - & 01 & -.09 \\
\hline 17. Ethnic background ${ }^{\mathrm{C}}$ & & & & & & & & & & & & & & & & & - & -.08 \\
\hline
\end{tabular}

${ }^{\mathrm{a}}$ Sample size for this variable only $=389 ;{ }^{\mathrm{b}}$ Boys coded 1 , girls coded $0 ;{ }^{\mathrm{c}}$ Caucasian children coded 1 , non-Caucasian children coded 0 ; ${ }^{\mathrm{d}}$ Out-of-home care group coded 1 , not in care group coded $0 ;{ }^{*} p<.05,{ }^{* *} p<.01,{ }^{* * *} p<.001$. 
Table 3

Hierarchical Multiple Regression Analyses Predicting Career Aspirations, Job Complexity, Career Exploration and Career Planning

\begin{tabular}{|c|c|c|c|c|c|c|c|c|}
\hline \multirow[b]{2}{*}{ Variables } & \multicolumn{2}{|c|}{$\begin{array}{c}\text { Career } \\
\text { Aspirations }\end{array}$} & \multicolumn{2}{|c|}{$\begin{array}{c}\text { Job } \\
\text { Complexity }\end{array}$} & \multicolumn{2}{|c|}{$\begin{array}{c}\text { Career } \\
\text { Exploration }\end{array}$} & \multicolumn{2}{|c|}{$\begin{array}{l}\text { Career } \\
\text { Planning }\end{array}$} \\
\hline & $\Delta R^{\frac{1}{2}}$ & $\beta$ & $\Delta R^{2}$ & $\beta$ & $\Delta R^{\frac{1}{2}}$ & $\beta$ & $\Delta R^{2}$ & $\beta$ \\
\hline $\begin{array}{l}\text { Step } 1 \\
\text { Control variables }{ }^{\text {a }}\end{array}$ & $.04 * *$ & & $.09 * *$ & & $.06^{* * *}$ & & $.12^{* *}$ & \\
\hline Step 2 & $.35 * *$ & & $.14^{* *}$ & & $.33 * *$ & & $.47 * *$ & \\
\hline Job complexity & & .01 & & - & & .02 & & -.00 \\
\hline Career aspirations & & - & & .02 & & $.14^{* *}$ & & $.11^{* *}$ \\
\hline Career planning & & $.17^{* *}$ & & -.01 & & $.31 * * *$ & & - \\
\hline Career exploration & & $.14^{* *}$ & & .02 & & - & & $.21^{* * *}$ \\
\hline Career self-efficacy & & $.13^{*}$ & & .01 & & .04 & & $.35 * * *$ \\
\hline Career outcome expectations & & $.32 * * *$ & & -.10 & & $.16^{*}$ & & $.17 * *$ \\
\hline Barriers (Person) & & -.03 & & .02 & & .06 & & .04 \\
\hline Barriers (External) & & .06 & & -.05 & & .02 & & .02 \\
\hline Educational aspirations (Self) & & .01 & & $.22 * * *$ & & .07 & & .06 \\
\hline Educational aspirations (Parents) & & .03 & & $.20 * *$ & & -.02 & & -.02 \\
\hline Educational aspirations (Friends) & & .04 & & -.02 & & .03 & & .03 \\
\hline School stability & & .02 & & .01 & & .03 & & -.03 \\
\hline School engagement & & $-.10 *$ & & .08 & & .09 & & .06 \\
\hline Group & & .02 & & -.08 & & .01 & & $-.13 * *$ \\
\hline Step 3 & .03 & & .02 & & $.04 *$ & & .02 & \\
\hline Job complexity x Group & & .03 & & - & & .03 & & -.01 \\
\hline Career aspirations x Group & & - & & .01 & & $-.15^{*}$ & & $.17 * *$ \\
\hline Career planning x Group & & $.28^{* *}$ & & -.04 & & -.05 & & - \\
\hline Career exploration x Group & & -.11 & & .03 & & - & & -.01 \\
\hline Career self-efficacy x Group & & -.08 & & .07 & & $.26 * *$ & & -.13 \\
\hline Outcome expectations x Group & & -.07 & & -.07 & & -.11 & & -.03 \\
\hline Barriers (Person) x Group & & .04 & & .03 & & .02 & & -.03 \\
\hline Barriers (External) x Group & & .08 & & .07 & & -.13 & & .09 \\
\hline Educational aspirations (Self) x Group & & .17 & & -.21 & & .08 & & -.02 \\
\hline Educational aspirations (Parents) x Group & & -.11 & & .06 & & $-.18 *$ & & .10 \\
\hline Educational aspirations (Friends) x Group & & -.03 & & .00 & & $.13^{*}$ & & .02 \\
\hline School stability x Group & & .05 & & $-.20 *$ & & .02 & & -.10 \\
\hline School engagement x Group & & -.05 & & -.01 & & .04 & & -.06 \\
\hline Total $R^{2}$ & $.42^{* *}$ & & $.25^{* *}$ & & $.43^{* *}$ & & $.61^{* *}$ & \\
\hline$N$ & 404 & & 404 & & 389 & & 404 & \\
\hline
\end{tabular}

Note. ${ }^{a}$ Educational achievement included as control variable in all analyses; age also included for career exploration; “-” indicates variable omitted for that analysis; * $=p<.05$, ** $=p<.01$, *** $=p<$ .001 . 

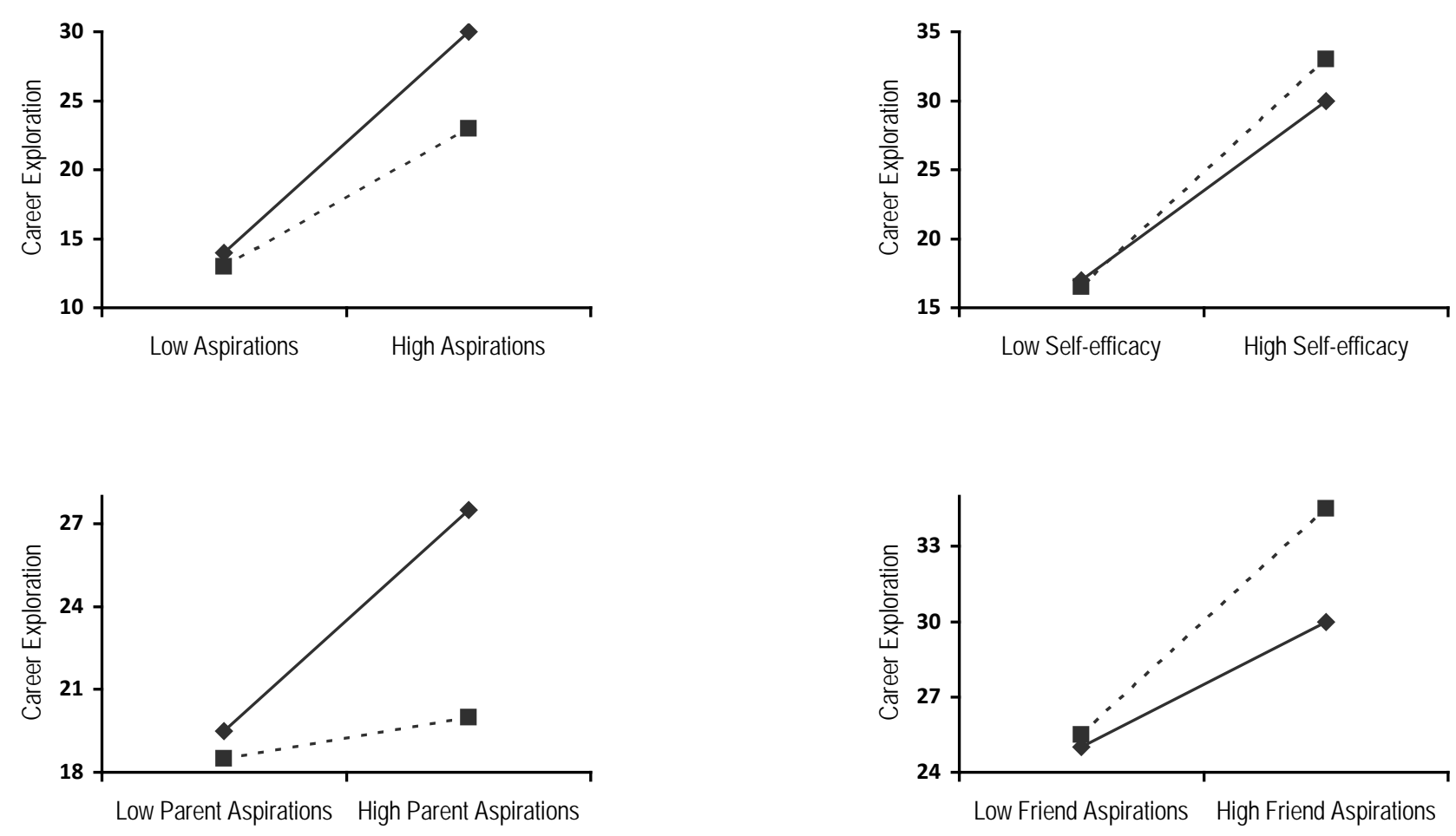

Figure 1. Interaction effects: career aspirations $\mathrm{x}$ group, career decision self-efficacy $\mathrm{x}$ group, educational aspirations of parents $\mathrm{x}$ group, educational aspirations of friends $\mathrm{x}$ group. Full line $=$ not in care group; broken line = in out-of-home care group. 